\title{
Technical note: New particle formation event forecasts during PEGASOS-Zeppelin Northern mission 2013 in Hyytiälä, Finland
}

\author{
T. Nieminen ${ }^{1,2}$, T. Yli-Juuti ${ }^{1,3,4}$, H. E. Manninen ${ }^{1}$, T. Petäjä ${ }^{1}$, V.-M. Kerminen ${ }^{1}$, and M. Kulmala ${ }^{1}$ \\ ${ }^{1}$ Department of Physics, University of Helsinki, P.O. Box 64, 00014, University of Helsinki, Finland \\ ${ }^{2}$ Helsinki Institute of Physics, P.O. Box 64, 00014, University of Helsinki, Finland \\ ${ }^{3}$ Multiphase Chemistry Department, Max Planck Institute for Chemistry, Hahn-Meitner Weg 1, 55128 Mainz, Germany \\ ${ }^{4}$ Department of Applied Physics, University of Eastern Finland, P.O. Box 1627, 70211 Kuopio, Finland
}

Correspondence to: T. Nieminen (tuomo.nieminen@ helsinki.fi)

Received: 4 November 2014 - Published in Atmos. Chem. Phys. Discuss.: 27 January 2015

Revised: 16 October 2015 - Accepted: 19 October 2015 - Published: 9 November 2015

\begin{abstract}
New particle formation (NPF) occurs frequently in the global atmosphere. During recent years, detailed laboratory experiments combined with intensive field observations in different locations have provided insights into the vapours responsible for the initial formation of particles and their subsequent growth. In this regard, the importance of sulfuric acid, stabilizing bases such as ammonia and amines as well as extremely low volatile organics, have been proposed. The instrumentation to observe freshly formed aerosol particles has developed to a stage where the instruments can be implemented as part of airborne platforms, such as aircrafts or a Zeppelin-type airship. Flight measurements are technically more demanding and require a greater detail of planning than field studies at the ground level. The high cost of flight hours, limited time available during a single research flight for the measurements, and different instrument payloads in Zeppelin airship for various flight missions demanded an analysis tool that would forecast whether or not there is a good chance for an NPF event. Here we present a methodology to forecast NPF event probability at the SMEAR II site in Hyytiälä, Finland. This methodology was used to optimize flight hours during the PEGASOS (Pan-European Gas Aerosol Climate Interaction Study)-Zeppelin Northern mission in May-June 2013. Based on the existing knowledge, we derived a method for estimating the nucleation probability that utilizes forecast air mass trajectories, weather forecasts, and air quality model predictions. With the forecast tool we were able to predict the occurrence of NPF events for the next day with more than $90 \%$ success rate (10 out of 11 NPF event days correctly predicted). To our knowledge, no similar forecasts of NPF
\end{abstract}

occurrence have been developed for other sites. This method of forecasting NPF occurrence could be applied also at other locations, provided that long-term observations of conditions favouring particle formation are available.

\section{Introduction}

Formation and growth of secondary aerosol particles has been observed in numerous locations and in different environments in the planetary boundary layer (for an overview see, e.g. Kulmala et al., 2004; Kulmala and Kerminen, 2008). Numerous investigations have attempted to connect new particle formation (NPF) to atmospheric trace gas concentrations, atmospheric chemistry, and meteorological processes (e.g. Weber et al., 1995; Riipinen et al., 2007; Paasonen et al., 2010). Most of the NPF observations are based on stationary ground-level measurements during which the sampled air masses and prevailing meteorological conditions are continuously changing. Typically the growth of the newly formed particles can be followed for several hours from these fixed point measurements, indicating that NPF usually occurs over large areas (Dal Maso et al., 2007; Hussein et al., 2009). In order to obtain more information on the spatial extent of NPF events both in the vertical and horizontal directions, measurements using aircrafts are needed. As part of the 4-year-long EU funded PEGASOS (Pan-European Gas Aerosol Climate Interaction Study) project, a Zeppelin NT (Neue Technologie) airship was performing atmospheric aerosol, trace gas, and photochemistry measurement flights in central Finland 
during May-June 2013. In order to most efficiently utilize the flight hours of the airship, it was necessary to prepare forecasts on the probability of NPF events in the coming days.

Most of the Zeppelin measurement flights during the campaign were directed to the vicinity of the University of Helsinki SMEAR II measurement station in Hyytiälä (Hari and Kulmala, 2005). Measurements of aerosol number-size distributions, trace gas concentrations and basic meteorological quantities were started at the SMEAR II station in January 1996. These long time-series records have been used extensively to characterize the conditions in which NPF occurs (or does not occur) in this boreal forest environment, based on both the local atmospheric conditions as well as the synoptic situation and air mass origins and transport route to the station (Boy and Kulmala, 2002; Boy et al., 2003; Lyubovtseva et al., 2005; Dal Maso et al., 2007; Sogacheva et al., 2008; Nieminen et al., 2014).

Field observations, laboratory experiments, and theoretical considerations have shown that sulfuric acid is one of the key components in atmospheric NPF events, but in addition also trace amounts of other vapours such as ammonia, amines, or oxidized organics are needed (e.g. Kulmala et al., 2013). Particularly the contribution of extreme low volatile organics seems to be crucial in the boreal forest environment (Kulmala et al., 1998; Yli-Juuti et al., 2011; Ehn et al., 2014). Proxies for the concentrations of these trace gases or their precursors have been developed based on campaign-wise measurements (Petäjä et al., 2009; Lappalainen et al., 2009). Based on the concentrations and emissions of these trace gases, several parameterizations have been developed to describe the occurrence and intensity of NPF (e.g. Buzorius et al., 2003; Bonn et al., 2008; Paasonen et al., 2010; Häkkinen et al., 2013).

In this work, we describe forecasts for the occurrence of NPF at the SMEAR II station. The forecasts are based on the above-mentioned long-term time series observations of the typical conditions during NPF days and non-NPF days, the air mass origins as well as weather and air-quality forecasts.

\section{Materials and methods}

The main objective of the NPF forecasts was to predict whether during the next 3 days NPF events were likely to occur at the SMEAR II station area. A time period of 3 days was chosen in order to have long enough time for preparing the measurement instruments needed on different flights while still maintaining reliability of the input data used in making the NPF forecasts. The final NPF forecast was always provided for the next day, as the Zeppelin measurement flights were typically planned 1 day in advance. All the NPF forecast results presented in this work refer to the final NPF forecasts, i.e. forecasts for the next day.

\subsection{Predictions for trace gas concentrations, particulate matter, and meteorology}

Forecasts for concentrations of trace gases $\mathrm{SO}_{2}, \mathrm{O}_{3}, \mathrm{NO}_{x}$, $\mathrm{CO}$, and $\mathrm{OH}$ as well as particulate matter $\left(\mathrm{PM}_{10}\right.$, comprising the total mass concentration of particles smaller than $10 \mu \mathrm{m}$ in diameter), and relative humidity were obtained from the Finnish Meteorological Institute's SILAM (System for Integrated modeLling of Atmospheric coMposition) air quality model (Sofiev et al., 2006). This model provides predictions for the above-mentioned variables for the next 5 days at several heights above the ground. Input information for SILAM includes anthropogenic emissions from the TNOMACC data set, IS4FIRES information on wild fires, as well as emission calculations for sea salt, pollen, wind-blown dust, and natural volatile organic compounds. The weather forecast input data are obtained from the FMI HIRLAM model. The horizontal resolution of SILAM in the Scandinavian area is $6-7 \mathrm{~km}$. All SILAM forecast data are freely accessible via the internet (http://silam.fmi.fi/), and the forecast for the northern Europe area is updated once per day. For the purpose of the current NPF event forecasts, we used predictions for the ground level ( $15 \mathrm{~m}$ above ground) during next 3 days from the model grid point nearest to Hyytiälä SMEAR II station with the time resolution of $1 \mathrm{~h}$.

As supporting data, we also used several "traditional" weather forecasts available on the internet (including forecasts by the Finnish Meteorological Institute, Foreca, and Norwegian Meteorological Institute), mainly to evaluate the probabilities of cloudiness and rain. During the campaign time, the weather was rather variable and the forecasts were changing rapidly (even several times a day) from clear skies to partly cloudy and possibly rainy. All these conditions are known to affect directly the probability of NPF.

\subsection{Air-mass back trajectories}

Air mass arrival directions and source areas were forecast for $96 \mathrm{~h}$ prior to the arrival of air at Hyytiälä using the HYSPLIT single particle Lagrangian transport model developed by NOAA and freely available on the internet (http: //www.arl.noaa.gov/HYSPLIT.php). As input meteorological data for the model, we used the US National Weather Service's Global Forecasting System (GFS) weather forecast data which extend $192 \mathrm{~h}$ forwards in time. The horizontal location accuracy of the air mass trajectory calculations using HYSPLIT has been estimated to be on the order of 10-30\% of the total distance the air parcel has travelled (Stunder, 1996; Stohl, 1998; Draxler and Hess, 1998, 2010). We considered trajectories arriving each hour to Hyytiälä at $250 \mathrm{~m}$ height above ground calculated $96 \mathrm{~h}$ backwards in time. Typically air masses travelled less than $1000 \mathrm{~km}$ during this time, meaning that the air mass source area predictions based on the back trajectory calculations could be considered accurate within $100-300 \mathrm{~km}$ or better. Also, since we did not consider 
Table 1. Conditions observed at Hyytiälä during NPF and non-NPF days between 08:00 and 11:00 (local time) in months May-June 1996-2012. For each variable the median value is given and the interquartile range (25th and 75th percentiles) is shown in brackets. The median and interquartile values are calculated from all data at 30 min time resolution in the time window 08:00-11:00.

\begin{tabular}{|c|c|c|}
\hline Parameter & NPF day & Non-NPF day \\
\hline Temperature $\left({ }^{\circ} \mathrm{C}\right)$ & $11(8-14)$ & $13(9-17)$ \\
\hline Global radiation $\left(\mathrm{W} \mathrm{m}^{-2}\right)$ & $560(430-610)$ & $230(120-530)$ \\
\hline Relative humidity (\%) & $45(39-55)$ & $76(59-91)$ \\
\hline $\mathrm{H}_{2} \mathrm{O}$ (parts-per-thousand) & $6.5(4.9-8.0)$ & $10.2(8.6-12.4)$ \\
\hline $\mathrm{SO}_{2}(\mathrm{ppb})$ & $0.12(0.04-0.23)$ & $0.09(0.04-0.19)$ \\
\hline $\mathrm{O}_{3}(\mathrm{ppb})$ & $39(35-44)$ & $34(28-41)$ \\
\hline Condensation sink $\left(10^{-3} \mathrm{~s}^{-1}\right)$ & $2.2(1.4-3.3)$ & $3.9(2.7-6.2)$ \\
\hline $\mathrm{PM}_{10}\left(\mu \mathrm{g} \mathrm{m}^{-3}\right)$ & $3.7(2.3-5.5)$ & $6.6(4.6-10.5)$ \\
\hline
\end{tabular}

just individual air-mass back trajectories but rather took into account all the air masses that were to arrive during the morning and early afternoon (which is the typical time of NPF occurrence in Hyytiälä), the effect of uncertainties in the position of individual trajectories was diminished.

\subsection{NPF event forecasts and nucleation probability parameters}

Typical conditions on NPF and non-NPF days in Hyytiälä are shown in Table 1 for May and June during years 1996-2012. The conditions are shown for the time window 08:00-11:00, which is the time when NPF typically starts in Hyytiälä. In a data-mining study of the SMEAR II station long time-series records of aerosol size distributions and meteorological parameters, Hyvönen et al. (2005) found that the condensation sink (describing the pre-existing aerosol surface area) and relative humidity were the two parameters most effectively separating NPF days from non-NPF days. Particle formation was occurring only on days with a low CS and low RH. On the other hand, photochemical production of vapours participating in nucleation and growth, namely sulfuric acid and oxidation products of organics, is more efficient in clearsky conditions with high UV radiation intensity compared to cloudy conditions. Thus, our main criteria in forecasting NPF to occur were clear sky conditions, low condensation sink (in practice low $\mathrm{PM}_{10}$ concentration, which was obtained from SILAM) and from low relative humidity in the early morning to noon-time, as this is the time when regional NPF events start in Hyytiälä (Kulmala et al., 2013). Note that in spring and summertime, days with low relative humidity are typically also warm and sunny, so these conditions are not necessarily independent of each other. However, the difference between NPF days and non-NPF days is also seen in the absolute humidity (water vapour concentration, see Table 1).

The air mass source area and transport route to Hyytiälä were considered when making the NPF forecasts. In the long time-series analysis by Dal Maso et al. (2007), the occurrence of NPF in Hyytiälä was observed to be highly favourable in air masses originating from the Arctic and North Atlantic oceans, and on the other hand suppressed in southern air masses. This is typically connected to clean air arriving from the west and more polluted air originating from central and eastern Europe, directly influencing the sink for newly formed particles. However, in air masses originating from the south and south-east to Hyytiälä, $\mathrm{SO}_{2}$ concentrations are typically higher than in westerly air masses, which would favour NPF due to a higher production rate of sulfuric acid (Riuttanen et al., 2013). Table 2 summarizes the criteria used for making the NPF forecasts. The flowchart representing the main decision making process for the NPF forecasts is shown in Fig. 1. The threshold values for $\mathrm{SO}_{2}$ and $\mathrm{PM}_{10}$ shown in the flowchart are based on the observed range of these variables on NPF and non-NPF days (Table 1).

We also developed several "nucleation parameters" to forecast the intensity of NPF. The parameters that worked best were either related to only the proxy concentration of sulfuric acid, or were related to proxies for both sulfuric acid and oxidation products of volatile organic compounds (such as monoterpenes). Paasonen et al. (2010) studied several different parameterizations for the formation rate of $2 \mathrm{~nm}$ particles, and found that at the Hyytiälä site nucleation rate could be mainly explained by the sulfuric acid concentration to the power of 1 or 2.

The simplest nucleation parameter is described by the following equation:

$\mathrm{NP}_{1}=\frac{\left[\mathrm{SO}_{2}\right] \cdot[\mathrm{OH}]}{\mathrm{PM}_{10} \cdot \mathrm{RH}}$

where the sulfur dioxide concentration $\left(\mathrm{SO}_{2}\right)$, hydroxyl radical concentration $(\mathrm{OH})$, particulate mass concentration $\left(\mathrm{PM}_{10}\right)$ and relative humidity $(\mathrm{RH})$ are taken from the SILAM air quality forecasts for the grid point closest to Hyytiälä. The particulate mass concentration is available from the SILAM forecasts. In Hyytiälä, the $\mathrm{PM}_{10}$ concentrations correlate well with the condensation sink CS which describes the total sink of the newly formed particles due to the pre-existing aerosol population. The $\mathrm{PM}_{10}$ concentrations (in units $\mu \mathrm{g} \mathrm{m}^{-3}$ ) can be scaled to CS (in units $\mathrm{s}^{-1}$ ) using the linear relationship $\mathrm{CS}=4.59 \times 10^{-4} \times \mathrm{PM}_{10}$ (linear regression based on measurement data from Hyytiälä in 1996-2012 with correlation coefficient $r=0.81$ ). The relative humidity is included as $\mathrm{RH}^{-1}$ in Eq. (1) in order to take into account the observed anti-correlation between the relative humidity and particle formation intensity, mainly due to the fact that the highest sulfuric acid concentrations are limited to times of low ambient relative humidity (Hamed et al., 2011).

A nucleation parameter taking into account the oxidation products of monoterpenes, in addition to sulfuric acid, is described by the following equation:

$\mathrm{NP}_{2}=\frac{\left[\mathrm{SO}_{2}\right] \cdot[\mathrm{OH}]}{\mathrm{PM}_{10} \cdot \mathrm{RH}} \cdot \frac{\exp (a T) \cdot\left(k_{\mathrm{OH}}[\mathrm{OH}]+k_{\mathrm{O}_{3}}\left[\mathrm{O}_{3}\right]\right)}{\mathrm{BLH} \cdot \mathrm{PM}_{10}}$ 


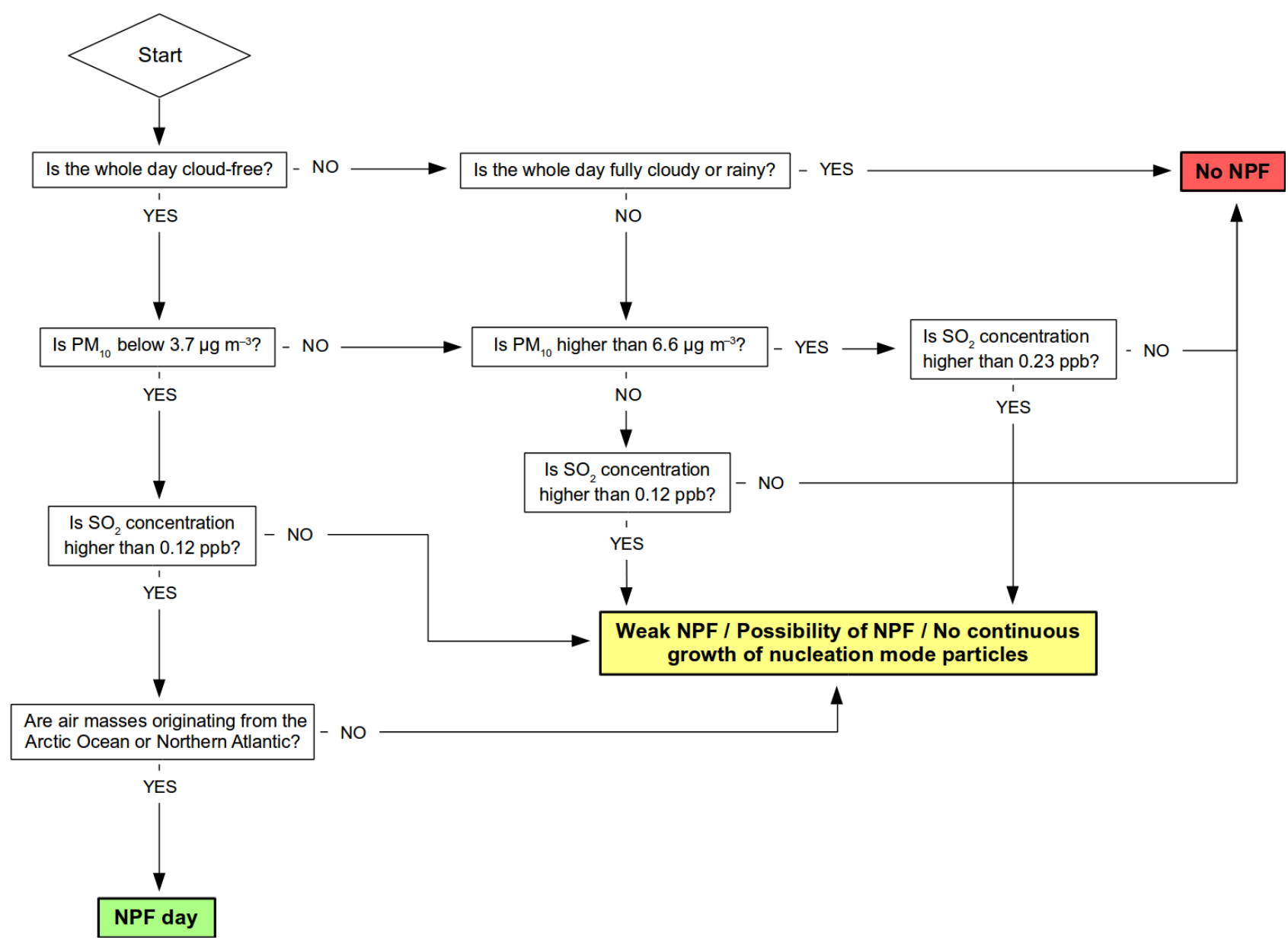

Figure 1. Flowchart of the decision making process for the NPF forecasts.

Here, the concentrations of sulfur dioxide $\mathrm{SO}_{2}$, hydroxyl radicals $\mathrm{OH}$ and ozone $\mathrm{O}_{3}$ (in units of $\mathrm{cm}^{-3}$ ), particulate mass $\mathrm{PM}_{10}$ (in units $\mu \mathrm{g} \mathrm{m}^{-3}$ ), as well as relative humidity RH (in percentages), and temperature $T$ (in units ${ }^{\circ} \mathrm{C}$ ) were obtained from the SILAM forecasts. The concentrations of monoterpenes were predicted based on the ambient temperature, as their concentrations have been shown to follow an exponential temperature dependence in Hyytiälä with the scaling coefficient $a=0.078^{\circ} \mathrm{C}^{-1}$ (Lappalainen et al., 2009). The $\mathrm{OH}$ and $\mathrm{O}_{3}$ concentrations were used to calculate the proxy concentrations of the monoterpene oxidation products, and the reaction coefficients $k_{\mathrm{OH}}=7.5 \times 10^{-11}$ and $k_{\mathrm{O}_{3}}=1.4 \times 10^{-17} \mathrm{~cm}^{3} \mathrm{~s}^{-1}$ are the averages of the reaction coefficients for individual monoterpene species weighted according to their typical concentrations observed in Hyytiälä (Hakola et al., 2003; Yli-Juuti et al., 2011). The modelled boundary layer height BLH is included in Eq. (2) to take into account the dilution of monoterpene emissions into the developing boundary layer.

\section{Results}

\subsection{Overview of the conditions during the campaign}

The PEGASOS-Zeppelin Northern mission was a 40day-long measurement campaign between 3 May and 11 June 2013. An overview of the meteorological conditions as well as trace gas and particle concentrations observed at the SMEAR II station during the campaign is shown in Fig. 2. Most of the days were sunny with either clear or partly clear skies. Rain occurred on 13 days during the campaign. The air was rather clean from anthropogenic pollution, especially in the first and last week of the campaign. Occasionally, there were pollution episodes seen e.g from a 10 -fold rise of the $\mathrm{SO}_{2}$ concentration from its typical level of about $0.1 \mathrm{ppb}$. At the end of May, a longer period occurred during which more polluted continental air was transported from central Europe to Hyytiälä.

Figure 3 shows the arrival routes of air masses to Hyytiälä during the period of our measurement campaign. These trajectories were calculated for the $250 \mathrm{~m}$ arrival height above ground, and $96 \mathrm{~h}$ backwards in time. From the beginning of 


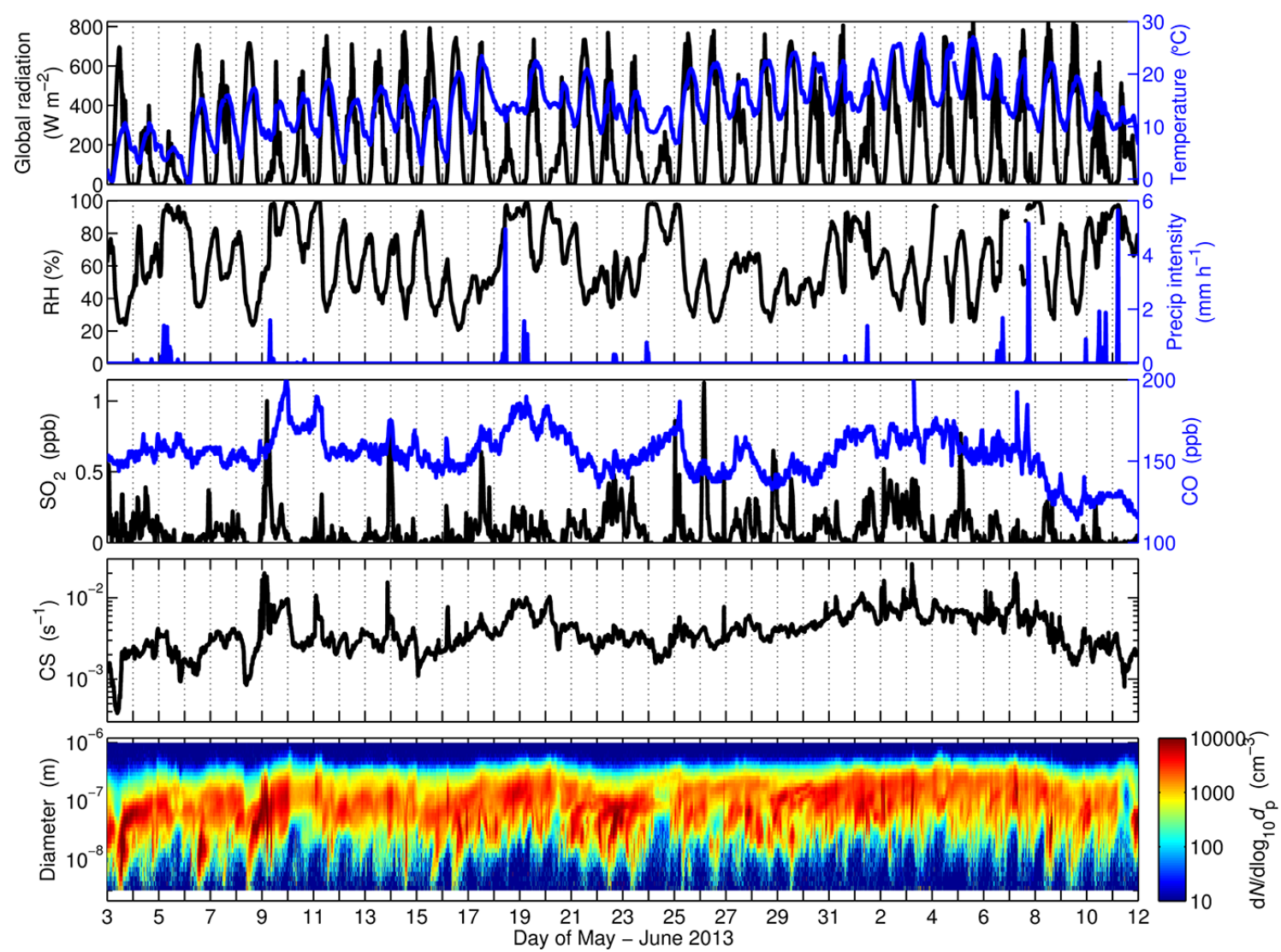

Figure 2. Overview of the meteorological parameters, trace gas concentrations and particle size distributions during the campaign 3 May11 June 2013.

Table 2. Criteria for the NPF forecasts (the source for each data is shown in parentheses). All the criteria within the category must be fulfilled; i.e. the individual criteria are combined with logical operator AND.

\begin{tabular}{|c|c|}
\hline NPF forecast & Criteria \\
\hline NPF day & $\begin{array}{l}\text { Sunny, clear skies (according to weather forecasts) } \\
\text { Low PM } 10 \text { concentration, smaller than } 3.7 \mu \mathrm{g} \mathrm{m}^{-3} \text { (SILAM) } \\
\text { Low RH during the day, smaller than } 45 \% \text { (SILAM) } \\
\mathrm{SO}_{2} \text { concentration higher than } 0.12 \mathrm{ppb} \text { (SILAM) } \\
\text { Air masses originating from the Arctic Ocean or the North Atlantic (HYSPLIT } \\
\text { trajectories) }\end{array}$ \\
\hline $\begin{array}{l}\text { Weak NPF/ possibility of NPF/ no } \\
\text { continuous growth of nucleation mode } \\
\text { particles }\end{array}$ & $\begin{array}{l}\text { Sunny day with some clouds, or partly cloudy (according to weather forecasts) } \\
\mathrm{PM}_{10} 3.7-6.6 \mu \mathrm{g} \mathrm{m}^{-3} \text { and } \mathrm{SO}_{2}>0.12 \mathrm{ppb} \text {; OR } \mathrm{PM}_{10}>6.6 \mu \mathrm{g} \mathrm{m}^{-3} \text { and } \mathrm{SO}_{2} \\
>0.23 \mathrm{ppb} \text { (SILAM) } \\
\mathrm{RH} \text { during the day } 45-76 \% \text { (SILAM) } \\
\text { Air masses not coming directly from the west-north-west, or passing over } \\
\text { known areas of anthropogenic pollution (HYSPLIT trajectories) }\end{array}$ \\
\hline No NPF & $\begin{array}{l}\text { Cloudy day, rain (according to weather forecasts) } \\
\text { High } \mathrm{PM}_{10} \text {, higher than } 6.6 \mu \mathrm{g} \mathrm{m}^{-3} \text { (SILAM) } \\
\text { High } \mathrm{RH} \text {, higher than } 76 \% \text { (SILAM) } \\
\mathrm{SO}_{2} \text { concentration smaller than } 0.09 \mathrm{ppb} \text { (SILAM) } \\
\text { Air masses originating from the south (continental Europe) or east, or passing } \\
\text { over known areas of anthropogenic pollution (HYSPLIT trajectories) }\end{array}$ \\
\hline
\end{tabular}




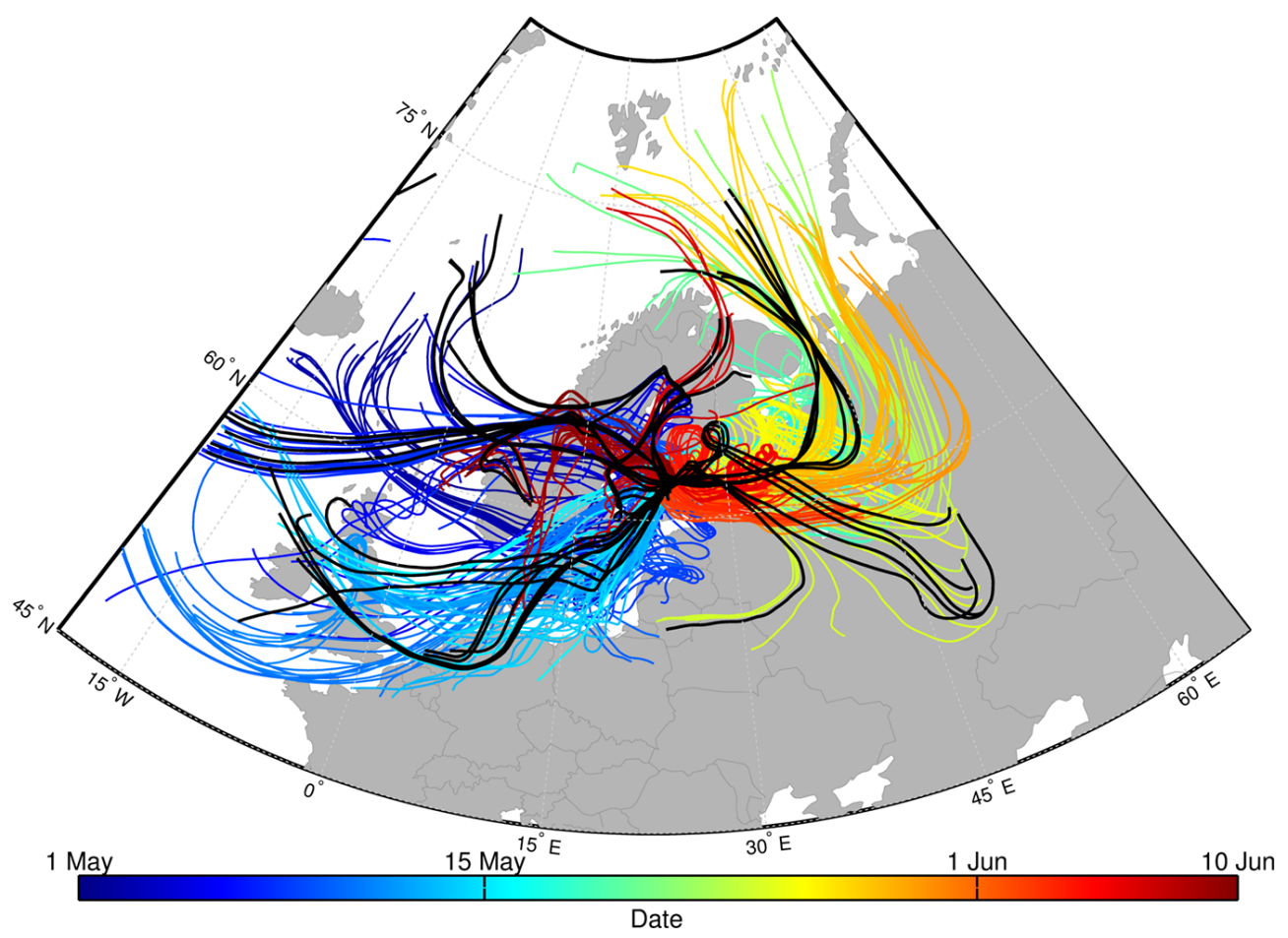

Figure 3. Air mass arrival trajectories to Hyytiälä 3 May-11 June 2013 calculated using HYSPLIT model. The colour indicates the arrival date and each trajectory represents air mass route during $96 \mathrm{~h}$ before arrival. Air mass trajectories arriving on NPF days between 10:00-14:00 local time are marked with black lines.

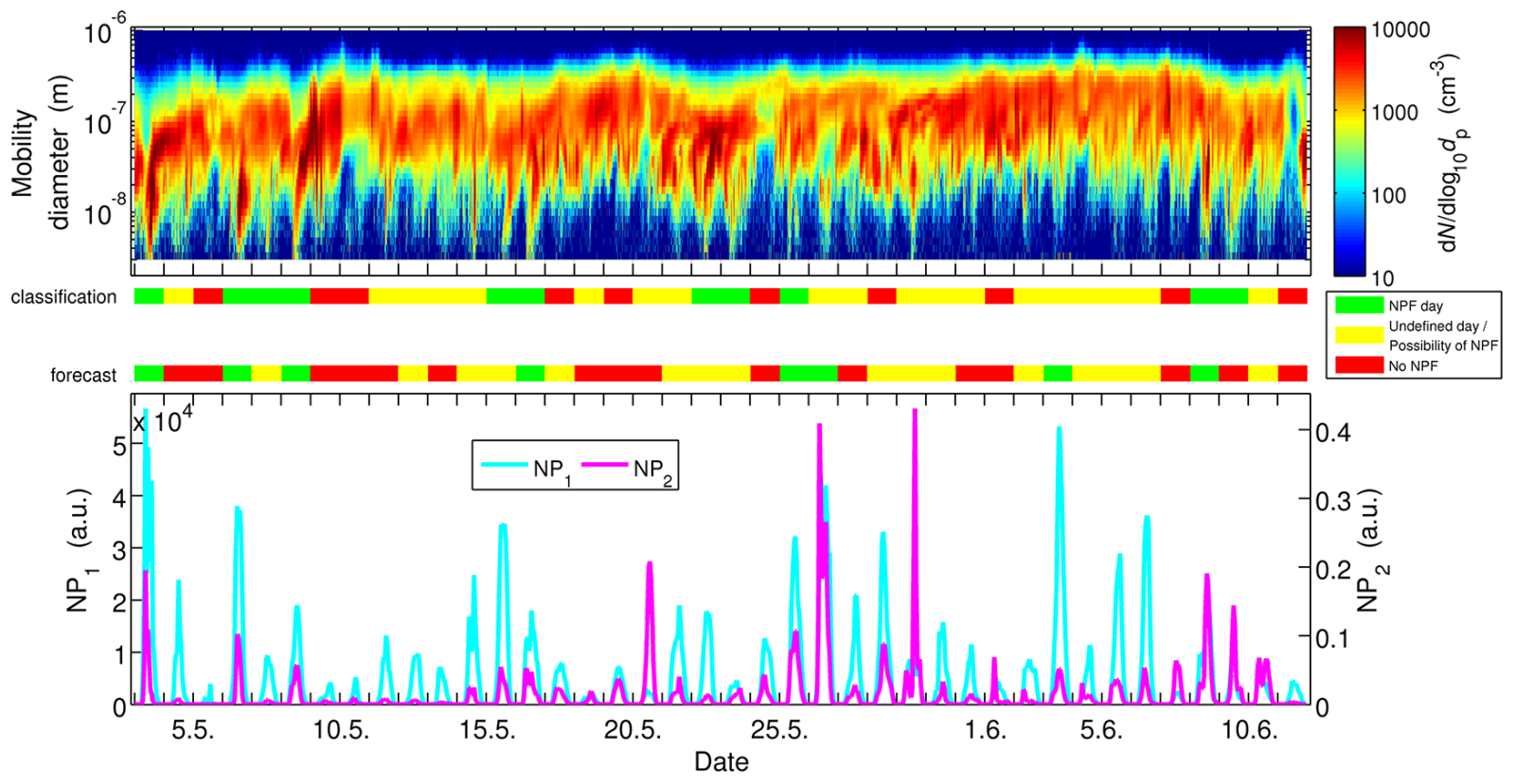

Figure 4. Particle number concentration size distributions (top panel), and nucleation parameters $\mathrm{NP}_{1}$ and $\mathrm{NP}_{2}$ (bottom panel) during the campaign time 3 May-11 June 2013. The colour bars between the panels indicate the NPF forecast and classification: green for NPF days, yellow for weak or possible NPF days, and red for non-NPF days (upper colour bar shows the NPF event classification based on the DMPS data, and lower colour bar the forecast for each day).

the campaign until middle of May, approximately 17 May, the air masses originated mainly from over the Atlantic, and arrived at Hyytiälä either directly from the west over Scandinavia or from the south-west, making a turn over the Baltic 
Sea. Air in Hyytiälä was relatively clean during this time, characterized by low particulate mass and trace gas concentrations. Especially $\mathrm{SO}_{2}$ had very low concentrations during this time, with the exception of one pollution-related peak on 9 May. After mid-May, air masses turned to arrive mainly from east at Hyytiälä, originating either from over the Arctic Ocean or from the continental north-west Russia. During this time until early June, the condensation sink and $\mathrm{PM}_{10}$ concentrations were higher than in early May, indicating more polluted air. Also high concentration peaks in the trace gases $\mathrm{SO}_{2}$ and $\mathrm{CO}$ were more frequent during this time. During the last weeks of the campaign in the beginning of June, air masses turned again to arrive at Hyytiälä from the west over Scandinavia, resulting in cleaner air with low particulate matter and trace gas concentrations.

\subsection{Performance of the NPF forecasts and nucleation parameters}

Figure 4 shows the particle number size-distributions along with the forecasted NPF occurrence and the time series of the nucleation parameters $\mathrm{NP}_{1}$ and $\mathrm{NP}_{2}$. In the beginning of the campaign, several strong NPF bursts occurred (high nucleation mode particle concentrations on 3,6 , and 8 of May), and our forecasts were able to capture these as well as the days with no new particle formation. Both of the nucleation parameters peaked on these 3 NPF event days, and were clearly lower on the days between NPF events, except $\mathrm{NP}_{1}$, which had a relatively high value also on 4 May. During the beginning of the campaign time, air masses originated mainly from over the Atlantic Ocean and arrived at Hyytiälä after passing over Scandinavia. On some of these days, the air was remarkably clean, characterized by very low $\mathrm{SO}_{2}$ concentrations (below $0.1 \mathrm{ppb}$ ), resulting in low sulfuric acid concentrations and weak or no NPF event on clear-sky conditions. The daytime peak value of $10^{4}$ or higher for nucleation parameter $\mathrm{NP}_{1}$ was typically associated with the occurrence of NPF.

After mid-May until early June, the air masses arrived at Hyytiälä mainly from the east, either spending several days over continental Russia or, in some cases, coming more directly from over the Arctic Ocean via north-west Russia. The air mass circulation was driven by a persistent highpressure system residing over central Finland. This resulted in a rather unusual air mass transport pattern to Hyytiälä, and also made the NPF forecasting more challenging. During this time, there were situations when the polluted air masses resulted in a high condensation sink, preventing the occurrence of NPF. Also the SILAM forecasts for the $\mathrm{SO}_{2}$ and $\mathrm{PM}_{10}$ concentrations were less accurate during the easterly air masses compared with air masses coming from the west or the south. This might be related to less accurate emission data for these species over the Russian area.

The nucleation parameter $\mathrm{NP}_{2}$ started to have high values more frequently after the middle of May. One factor influ- encing this was the higher air temperatures during this time compared to the beginning of the campaign, as the emissions of monoterpenes are highly influenced by the ambient temperature. NPF events, however, were not as frequent during this time. On one hand, this period was influenced by the more polluted air masses arriving at Hyytiälä from the east. On the other hand this period included quite a few days (13 out of 22 days after 20 May) when a growing particle mode was observed to appear in Hyytiälä starting from sizes above $10-20 \mathrm{~nm}$. These types of NPF events are typically observed during the summertime in Hyytiälä, and they might be connected to higher particle growth rates during the summer, leading to the observation of the newly formed particles after they have already grown for several hours (Buenrostro Mazon et al., 2009). Days on which the maximum value of the nucleation parameter $\mathrm{NP}_{2}$ exceeded 0.02 started to be more likely an NPF event day rather than a non-event day.

The nucleation parameters $\mathrm{NP}_{1}$ and $\mathrm{NP}_{2}$ have a clear connection to the NPF: they represent the ratios between the source and sink terms for the newly formed particles. However, the numerical values for $\mathrm{NP}_{1}$ and $\mathrm{NP}_{2}$ and especially their uncertainty depend greatly on the weather forecast and air-quality forecast data taken from the SILAM model. As it is out of the scope of this work to evaluate the accuracy of the SILAM predictions for the various parameters used, the values of $\mathrm{NP}_{1}$ and $\mathrm{NP}_{2}$ presented in this study should be regarded as qualitative. When comparing the different days during the campaign, they did however provide useful information to support the NPF forecasting.

The particle number size distributions measured by the differential mobility particle sizer (DMPS) during the whole campaign are shown in the upper panel of Fig. 4. Using the criteria developed by Dal Maso et al. (2005), each day was classified as either an NPF event, non-event, or undefined day. On NPF event days a new mode of particles smaller than $25 \mathrm{~nm}$ is observed and these particles can be observed growing to larger sizes during several hours. NPF event days are further classified according to the possibility to reliably derive particle formation and growth rates (Class I) or not (Class II). The days when no new sub- $25 \mathrm{~nm}$ particles appeared were classified as non-NPF days. Undefined days are those days for which it was not possible to unambiguously determine whether NPF occurred or not. Table 3 shows the forecast and the corresponding event classification for each day. During the 40-day campaign, clear regional NPF events lasting for several hours were observed on 11 days in Hyytiälä. Six of these days were also forecast to be NPF days, and four to have a possibility of NPF to occur. The NPF day which we forecast to be a non-NPF day (9 June) was cloudy and had a possibility of rain according to weather forecasts, and the air masses were forecast to originate from the west, which is not the direction from where air masses typically arrive to Hyytiälä on NPF event days (Dal Maso et al., 2007). On 10 days of the campaign there was no particle formation occurring in Hyytiälä, and these were also fore- 
Table 3. NPF event forecasts (second column), and NPF event classification based on measured particle size distributions (third column) for each day of the campaign. Class I and II NPF events refer to the classification by Dal Maso et al. (2005). Remarks on the fourth column show the basis for the NPF event forecast.

\begin{tabular}{|c|c|c|c|}
\hline Date & Forecast & Classification & Remarks \\
\hline 3 May & Possibility of NPF & NPF (class II) & $\begin{array}{l}\text { Air masses coming from the north to north-west. Low } \mathrm{SO}_{2} \text { and } \mathrm{PM}_{10} \text {. Sunny } \\
\text { the whole morning until mid-afternoon. } \mathrm{RH} \text { drops to } 25 \% \text { during the day. }\end{array}$ \\
\hline 4 May & No NPF & Undefined & $\begin{array}{l}\text { Air masses coming from the south-west. Elevated } \mathrm{SO}_{2} \text { and } \mathrm{PM}_{10} \text { concentra- } \\
\text { tions. Cloudy day with small chance of occasional rain. }\end{array}$ \\
\hline 5 May & No NPF & No NPF & $\begin{array}{l}\text { Air masses coming from the south-west over southern Sweden, turning to west } \\
\text { late in evening. Low } \mathrm{SO}_{2} \text { and } \mathrm{PM}_{10} \text { concentration. Cloudy day with light rain } \\
\text { throughout the day until evening. In the evening partly cloudy. }\end{array}$ \\
\hline 6 May & NPF day & NPF (class I) & $\begin{array}{l}\text { Air masses originating from the west and circulating over western Finland. Rel- } \\
\text { atively clean air, } \mathrm{SO}_{2} \text { and } \mathrm{PM}_{10} \text { concentrations low during morning and in- } \\
\text { creasing towards evening. Sunny until midday, afternoon clouds possible. RH } \\
\text { dropped to } 40 \% \text { during the morning. }\end{array}$ \\
\hline 7 May & $\begin{array}{l}\text { No continuous growth } \\
\text { of nucleation mode } \\
\text { particles }\end{array}$ & NPF (class II) & $\begin{array}{l}\text { Air masses coming from the south-west over Denmark and southern Sweden. } \\
\text { Elevated } \mathrm{SO}_{2} \text { and } \mathrm{PM}_{10} \text { concentrations. Partly cloudy day. RH dropped to } 55 \% \text {. }\end{array}$ \\
\hline 8 May & NPF day & NPF (class I) & $\begin{array}{l}\text { Westerly air masses coming over central Sweden. Low } \mathrm{SO}_{2} \text { and } \mathrm{PM}_{10} \text { concen- } \\
\text { trations. Sunny day, warm temperatures (over }+15^{\circ} \mathrm{C} \text { ). } \mathrm{RH} \text { dropped to } 35 \% \\
\text { during the morning. }\end{array}$ \\
\hline 9 May & No NPF & No NPF & $\begin{array}{l}\text { Air masses coming from the south-west-south and circulating over southern } \\
\text { Finland. Elevated } \mathrm{SO}_{2} \text { and } \mathrm{PM}_{10} \text { concentrations. Cloudy and rainy day. }\end{array}$ \\
\hline 10 May & No NPF & No NPF & $\begin{array}{l}\text { Air masses coming from the south over Baltic countries and southern Finland. } \\
\text { Low } \mathrm{SO}_{2} \text { and somewhat elevated } \mathrm{PM}_{10} \text { concentrations. Cloudy day with occa- } \\
\text { sional light rain. }\end{array}$ \\
\hline 11 May & No NPF & Undefined & $\begin{array}{l}\text { Air masses coming from the south-west over northern Germany, Denmark, and } \\
\text { southern Sweden. Low } \mathrm{SO}_{2} \text {, somewhat elevated } \mathrm{PM}_{10} \text { concentrations. Cloudy } \\
\text { morning, partly cloudy in afternoon, small chance of rain. Clear skies in the } \\
\text { evening. }\end{array}$ \\
\hline 12 May & Weak NPF & Undefined & $\begin{array}{l}\text { Air masses from the south-west over northern France, Denmark and southern } \\
\text { Sweden. Elevated } \mathrm{SO}_{2} \text { and relatively low } \mathrm{PM}_{10} \text { concentrations. Partly cloudy, } \\
\left.\text { warm (over }+15^{\circ} \mathrm{C}\right), \mathrm{RH} \text { dropped to } 45 \% \text {. }\end{array}$ \\
\hline 13 May & No NPF & Undefined & $\begin{array}{l}\text { Air masses from the south-west over England, Denmark, and southern Sweden. } \\
\mathrm{SO}_{2} \text { concentration somewhat elevated, high } \mathrm{PM}_{10} \text { concentrations. Partly cloudy } \\
\left.\text { day, early morning sunny. Warm (over }+15^{\circ} \mathrm{C}\right), \mathrm{RH} \text { dropped to } 45 \% \text {. }\end{array}$ \\
\hline 14 May & Possibility of NPF & Undefined & $\begin{array}{l}\text { Air masses from the south-west over Denmark, and southern Sweden. Some- } \\
\text { what elevated } \mathrm{SO}_{2} \text { and relatively low } \mathrm{PM}_{10} \text { concentrations. Possibility for clear } \\
\left.\text { sky in the morning, more clouds in the afternoon. Warm day (over }+15^{\circ} \mathrm{C}\right), \mathrm{RH} \\
\text { dropped to } 40 \% \text {. }\end{array}$ \\
\hline 15 May & Possibility of NPF & NPF (class I) & $\begin{array}{l}\text { Air masses from the south-west over England, northern Germany and south- } \\
\text { ern Sweden. Somewhat elevated } \mathrm{SO}_{2} \text {. Low } \mathrm{PM}_{10} \text { concentrations. Partly cloudy } \\
\text { early morning (possibility for clear sky), clear sky in the afternoon. Warm (over } \\
+15^{\circ} \mathrm{C} \text { ). RH dropped to } 35 \% \text { during the day. }\end{array}$ \\
\hline 16 May & NPF day & NPF (class II) & $\begin{array}{l}\text { Air masses from the south-west over northern Germany and southern Sweden, } \\
\text { circulating over southern Finland. Low } \mathrm{SO}_{2} \text {. Low } \mathrm{PM}_{10} \text { concentrations. Clear } \\
\text { sky in the morning, possibility of some clouds towards afternoon, warm (over } \\
+15^{\circ} \mathrm{C} \text { ). RH dropped to } 35 \% \text { during the day. }\end{array}$ \\
\hline 17 May & $\begin{array}{l}\text { No continuous growth } \\
\text { of nucleation mode } \\
\text { particles }\end{array}$ & No NPF & $\begin{array}{l}\text { Air masses from the south-west over England, Germany, and southern Sweden, } \\
\text { towards afternoon circulating over northeast Russia. Low } \mathrm{SO}_{2} \text {. Slightly elevated } \\
\mathrm{PM}_{10} \text { concentrations. Partly cloudy, very warm }\left(\text { over }+20^{\circ} \mathrm{C}\right) \text {. RH dropped to } \\
45 \% \text { during the day. }\end{array}$ \\
\hline
\end{tabular}


Table 3. Continued.

\begin{tabular}{|c|c|c|c|}
\hline Date & Forecast & Classification & Remarks \\
\hline 18 May & No NPF & Undefined & $\begin{array}{l}\text { Air masses circulating over Finland and north-west Russia. High } \mathrm{SO}_{2} \text {, elevated } \\
\left.\mathrm{PM}_{10} \text { concentrations. Cloudy, some rain, warm (over }+15^{\circ} \mathrm{C}\right) . \mathrm{RH} \text { dropped to } \\
45 \% \text { during the day. }\end{array}$ \\
\hline 19 May & No NPF & No NPF & $\begin{array}{l}\text { Air masses coming from east. Low } \mathrm{SO}_{2} \text { and } \mathrm{PM}_{10} \text { concentrations. Cloudy and } \\
\text { some rain, very warm (over }+20^{\circ} \mathrm{C} \text { ). } \mathrm{RH} \text { dropped to } 50 \% \text { during the day. }\end{array}$ \\
\hline 20 May & No NPF & Undefined & $\begin{array}{l}\text { Air masses coming from east. Low } \mathrm{SO}_{2} \text { and } \mathrm{PM}_{10} \text { concentrations. Cloudy and } \\
\text { some rain in the morning, very warm (over }+20^{\circ} \mathrm{C} \text { ). } \mathrm{RH}>90 \% \text { during the day. }\end{array}$ \\
\hline 21 May & Possibility of NPF & Undefined & $\begin{array}{l}\text { Air masses coming from the northeast. Elevated } \mathrm{SO}_{2} \text {, low } \mathrm{PM}_{10} \text { concentra- } \\
\text { tions. Partly cloudy until afternoon (no continuous growth of nucleation mode } \\
\text { particles), possibly clear skies in the evening. Very warm (over }+20^{\circ} \mathrm{C} \text { ). } \mathrm{RH} \\
\text { dropped to } 55 \% \text { during the day. }\end{array}$ \\
\hline 22 May & Possibility of NPF & NPF (class II) & $\begin{array}{l}\text { Air masses coming from Arctic Ocean and circulating via north-west Russia. } \\
\text { Elevated } \mathrm{SO}_{2} \text { and } \mathrm{PM}_{10} \text { concentrations. Partly cloudy day, cloudier towards } \\
\text { the afternoon (no continuous growth of nucleation mode) with a chance of rain. } \\
\left.\text { Warm (over }+15^{\circ} \mathrm{C}\right) \text {. } \mathrm{RH} \text { dropped to } 45 \% \text { during the day. }\end{array}$ \\
\hline 23 May & Possibility of NPF & NPF (class II) & $\begin{array}{l}\text { Air masses coming from Arctic Ocean and circulating over north-west Russia. } \\
\text { Low } \mathrm{SO}_{2} \text { and } \mathrm{PM}_{10} \text { concentrations. Partly cloudy in the morning, cloudy skies } \\
\text { towards the evening (no continuous growth of nucleation mode). }\end{array}$ \\
\hline 24 May & No NPF & No NPF & $\begin{array}{l}\text { Air masses coming from Arctic Ocean and circulating via north-west Russia. } \\
\text { Low } \mathrm{SO}_{2} \text { and } \mathrm{PM}_{10} \text { concentrations. Cloudy day, chance of rain throughout the } \\
\text { day. }\end{array}$ \\
\hline 25 May & NPF day & NPF (class II) & $\begin{array}{l}\text { Air masses coming from the south-east and circulating over central Finland. } \\
\text { Low } \mathrm{SO}_{2} \text { and somewhat elevated } \mathrm{PM}_{10} \text { concentrations. Sunny day with few } \\
\text { clouds, very warm (over }+20^{\circ} \mathrm{C} \text { ), } \mathrm{RH} \text { dropped to } 35 \% \text { during the morning. }\end{array}$ \\
\hline 26 May & NPF day & NPF & $\begin{array}{l}\text { Air masses coming from east and circulating via northern Finland to Hyytiälä. } \\
\text { Low } \mathrm{SO}_{2} \text { and } \mathrm{PM}_{10} \text { concentrations. Sunny day, some clouds in the afternoon, } \\
\text { very warm (over }+20^{\circ} \mathrm{C} \text { ), RH dropped to } 35 \% \text { during the morning. }\end{array}$ \\
\hline 27 May & No NPF & Undefined & $\begin{array}{l}\text { Air masses coming from east. High } \mathrm{SO}_{2} \text { and elevated } \mathrm{PM}_{10} \text { concentrations. } \\
\text { Cloudy and a chance of rain in the morning, partly cloudy in the afternoon. }\end{array}$ \\
\hline 28 May & $\begin{array}{l}\text { No continuous growth } \\
\text { of nucleation mode par- } \\
\text { ticles }\end{array}$ & No NPF & $\begin{array}{l}\text { Air masses coming from Arctic Ocean via north-west Russia to Hyytiälä. Low } \\
\mathrm{SO}_{2} \text { and } \mathrm{PM}_{10} \text { concentrations. Partly cloudy in the morning, clear skies towards } \\
\text { afternoon. Very warm (over }+20^{\circ} \mathrm{C} \text { ), } \mathrm{RH} \text { dropped to } 35 \% \text { during the morning. }\end{array}$ \\
\hline 29 May & Possibility of NPF & Undefined & $\begin{array}{l}\text { Air masses coming from Arctic Ocean via north-west Russia to Hyytiälä. Low } \\
\mathrm{SO}_{2} \text { and } \mathrm{PM}_{10} \text { concentrations. Partly cloudy in the morning, clear skies towards } \\
\left.\text { the evening. Very warm (over }+20^{\circ} \mathrm{C}\right) \text {. }\end{array}$ \\
\hline 30 May & Possibility of NPF & Undefined & $\begin{array}{l}\text { Air masses coming from Arctic Ocean via north-west Russia to Hyytiälä. Low } \\
\mathrm{SO}_{2} \text { and low } \mathrm{PM}_{10} \text { concentrations. Partly cloudy, with chances of rain in the } \\
\text { evening. Very warm (over }+20^{\circ} \mathrm{C} \text { ), RH dropped to } 45 \% \text { during the morning. }\end{array}$ \\
\hline 31 May & No NPF & Undefined & $\begin{array}{l}\text { Air masses coming from Arctic Ocean via north-west Russia to Hyytiälä. Low } \\
\mathrm{SO}_{2} \text { and } \mathrm{PM}_{10} \text { concentrations. Partly cloudy and chances of rain showers dur- } \\
\text { ing the day. }\end{array}$ \\
\hline 1 June & No NPF & No NPF & $\begin{array}{l}\text { Air masses coming from the south-east. Low } \mathrm{SO}_{2} \text { and } \mathrm{PM}_{10} \text { concentrations. } \\
\text { Partly cloudy in the morning, more clouds towards afternoon, chances of light } \\
\text { rain in the afternoon the day. }\end{array}$ \\
\hline 2 June & Possibility of NPF & Undefined & $\begin{array}{l}\text { Air masses coming from the south-east. Elevated } \mathrm{SO}_{2} \text { and } \mathrm{PM}_{10} \text { concentrations. } \\
\text { Partly cloudy, very warm (over }+20^{\circ} \mathrm{C} \text { ), } \mathrm{RH} \text { dropped to } 45 \% \text { during the } \\
\text { morning. }\end{array}$ \\
\hline
\end{tabular}


Table 3. Continued.

\begin{tabular}{|c|c|c|c|}
\hline Date & Forecast & Classification & Remarks \\
\hline 3 June & NPF day & Undefined & $\begin{array}{l}\text { Air masses coming from the south-east. } \mathrm{High} \mathrm{SO}_{2} \text { and elevated } \mathrm{PM}_{10} \text { concen- } \\
\text { trations. Clear skies, some clouds in the afternoon, very warm }\left(\text { over }+25^{\circ} \mathrm{C}\right) \text {, } \\
\mathrm{RH} \text { dropped to } 35 \% \text { during the morning. }\end{array}$ \\
\hline 4 June & Possibility of NPF & Undefined & $\begin{array}{l}\text { Air masses coming from the south-east. Low } \mathrm{SO}_{2} \text { and } \mathrm{PM}_{10} \text { concentrations. } \\
\text { Partly cloudy morning, some rain in the afternoon, warm }\left(\text { over }+20^{\circ} \mathrm{C}\right) \text {. } \mathrm{RH} \\
\text { dropped to } 35 \% \text { during the day. }\end{array}$ \\
\hline 5 June & Possibility of NPF & Undefined & $\begin{array}{l}\text { Air masses coming from the south-east. Elevated } \mathrm{SO}_{2} \text { and low } \mathrm{PM}_{10} \text { concen- } \\
\text { trations. Clear sky in the morning, partly cloudy starting from noon, possibility } \\
\text { of rain in the evening, very warm (over }+25^{\circ} \mathrm{C} \text { ). } \mathrm{RH} \text { dropped to } 25 \% \text {. }\end{array}$ \\
\hline 6 June & Possibility of NPF & Undefined & $\begin{array}{l}\text { Air masses coming from east in the morning and turning to north-west in the } \\
\text { afternoon. High } \mathrm{SO}_{2} \text { and elevated } \mathrm{PM}_{10} \text { concentrations. Partly cloudy morning, } \\
\text { rain and thunderstorms in the afternoon, warm (over }+20^{\circ} \mathrm{C} \text { ). }\end{array}$ \\
\hline 7 June & No NPF & No NPF & $\begin{array}{l}\text { Air masses coming from the northeast. Low } \mathrm{SO}_{2} \text { and elevated } \mathrm{PM}_{10} \text { concentra- } \\
\text { tions. Cloudy, rain and thunderstorms, moderate temperature }\left(\text { over }+15^{\circ} \mathrm{C}\right) \text {. }\end{array}$ \\
\hline 8 June & NPF day & NPF (class II) & $\begin{array}{l}\text { Air masses coming from the west, circulating over Sweden. Elevated } \mathrm{SO}_{2} \text { and } \\
\text { low } \mathrm{PM}_{10} \text { concentrations. Almost clear sky in the morning, partly cloudy in the } \\
\text { afternoon, warm (over }+20^{\circ} \mathrm{C} \text { ). } \mathrm{RH} \text { dropped to } 25 \% \text { during the day. }\end{array}$ \\
\hline 9 June & No NPF & NPF (class II) & $\begin{array}{l}\text { Air masses coming from the west. Low } \mathrm{SO}_{2} \text { and } \mathrm{PM}_{10} \text { concentrations. } \\
\text { Cloudy/partly cloudy, rain in the afternoon, moderate temperature (over } \\
+15^{\circ} \mathrm{C} \text { ). } \mathrm{RH} \text { dropped to } 45 \% \text { during the day. }\end{array}$ \\
\hline 10 June & Possibility of NPF & Undefined & $\begin{array}{l}\text { Air masses coming from the north-west. Low } \mathrm{SO}_{2} \text { and } \mathrm{PM}_{10} \text { concentrations. } \\
\text { Almost clear sky in the early morning, partly cloudy towards noon, chance of } \\
\text { rain in the afternoon, moderate temperature }\left(\text { over }+15^{\circ} \mathrm{C}\right) \text {. }\end{array}$ \\
\hline 11 June & No NPF & No NPF & $\begin{array}{l}\text { Air masses coming from the north-west. Elevated } \mathrm{SO}_{2} \text { and } \mathrm{PM}_{10} \text { concentra- } \\
\left.\text { tions. Partly cloudy, chance of rain, moderate temperature (over }+15^{\circ} \mathrm{C}\right) \text {. } \mathrm{RH} \\
\text { dropped to } 50 \% \text { during the day. }\end{array}$ \\
\hline
\end{tabular}

Table 4. Comparison of the NPF classification based on DMPS data (rows), and the NPF forecasts (columns). On days marked in bold the forecasts were successful in predicting whether NPF occurred in Hyytiälä or not, and on days marked in italic the forecast was wrong according to observations. The days classified as undefined according to observations are left out of the comparison with forecasts.

\begin{tabular}{lccc}
\hline & $\begin{array}{l}\text { "NPF" } \\
\text { forecast } \\
\text { (8 days) }\end{array}$ & $\begin{array}{c}\text { "Weak NPF/Possibility of NPF/No } \\
\text { continuous growth" forecast } \\
(16 \text { days })\end{array}$ & $\begin{array}{c}\text { "Non-NPF" } \\
\text { forecast } \\
(16 \text { days })\end{array}$ \\
\hline $\begin{array}{l}\text { NPF day } \\
\text { observed } \\
(11 \text { days) }\end{array}$ & $\mathbf{6}$ & $\mathbf{4}$ & 1 \\
\hline $\begin{array}{l}\text { Undefined day } \\
\text { observed } \\
\text { (19 days) }\end{array}$ & 2 & 10 & 7 \\
\hline $\begin{array}{l}\text { Non-NPF day } \\
\text { observed } \\
\text { (10 days) }\end{array}$ & 0 & 2 & $\mathbf{8}$ \\
\hline
\end{tabular}

cast to be non-NPF days, except for 2 days (17 and 28 May) for which a possible NPF event was forecast. This was most probably caused by the very low $\mathrm{SO}_{2}$ concentration. On only one of the days forecast to be non-NPF day was there appearance and growth of new nucleation mode particles. 
Comparison of the event classification and the event forecasts is shown in Table 4. We follow the method of Hyvönen et al. (2005) for calculating the score indices for the performance of the event forecasts on the 21 days classified as either NPF or non-NPF days (undefined days are removed from this comparison). Out of these 21 days our forecasts had two false NPF event days (non-event day forecast to be either event or to have a possibility for event) giving a $10 \%$ false-event fraction, and one NPF event day forecast to be a non-event day giving a $5 \%$ missed-event fraction. The total error of the NPF forecasts (false and missed events) during the 21 classified days of the 40-day campaign was $(2+1) / 21=14 \%$, which is comparable to the performance of the classification methods presented in the study by Hyvönen et al. (2005).

\section{Summary and conclusions}

Here we present a way to forecast new particle formation events. Being able to make such forecasts accurately is very important, for example, when airborne measurements are performed. As a summary, we made an NPF forecast for 40 days. The forecasts were found to work reasonably well. Only 1 day when nucleation was forecast to occur was a nonnucleation event day. In total, 24 days were predicted to be either NPF event days or probable NPF event days; 10 days were NPF event days, 11 were undefined (when it could not be reliably determined whether NPF occurred or not), and 2 were non-event days.

The main challenges in making the NPF forecasts were to obtain as reliable input data as possible from SILAM, HYSPLIT, and weather forecasts. The methods utilized here are most likely also applicable to other locations where there is sufficiently long data sets available to characterize the conditions favourable for the occurrence of regional-scale particle formation. In urban areas, and within cities our methods are less likely to be applicable due to the day-to-day variation of emissions of vapours and particles from local anthropogenic sources.

Acknowledgements. This research is supported by the Academy of Finland Centre of Excellence programme (project numbers 1118615 and 272041). The EU FP7 project PEGASOS (project number 265148) is acknowledged for the Zeppelin NT measurements. T. Yli-Juuti acknowledges financial support from Max Planck Society. H. E. Manninen acknowledges support by the Finnish Cultural Foundation. The authors acknowledge the NOAA Air Resources Laboratory (ARL) for the provision of the HYSPLIT transport and dispersion model and READY website (http://www.ready.noaa.gov), and the Finnish Meteorological Institute for the publicly available SILAM air quality model forecasts used in this publication (http://silam.fmi.fi/).

Edited by: E. Nemitz

\section{References}

Bonn, B., Boy, M., Kulmala, M., Groth, A., Trawny, K., Borchert, S., and Jacobi, S.: A new parametrization for ambient particle formation over coniferous forests and its potential implications for the future, Atmos. Chem. Phys., 9, 8079-8090, doi:10.5194/acp-9-8079-2009, 2009.

Boy, M. and Kulmala, M.: Nucleation events in the continental boundary layer: Influence of physical and meteorological parameters, Atmos. Chem. Phys., 2, 1-16, doi:10.5194/acp-2-1-2002, 2002.

Boy, M., Rannik, Ü., Lehtinen, K. E. J., Tarvainen, V., Hakola, H., and Kulmala, M.: Nucleation events in the continental boundary layer: Long-term statistical analyses of aerosol relevant characteristics, J. Geophys. Res., 108, 4667, doi:10.1029/2003JD003838, 2003.

Buenrostro Mazon, S., Riipinen, I., Schultz, D. M., Valtanen, M., Dal Maso, M., Sogacheva, L., Junninen, H., Nieminen, T., Kerminen, V.-M., and Kulmala, M.: Classifying previously undefined days from eleven years of aerosol-particle-size distribution data from the SMEAR II station, Hyytiälä, Finland, Atmos. Chem. Phys., 9, 667-676, doi:10.5194/acp-9-667-2009, 2009.

Buzorius, G., Rannik, Ü., Aalto, P., Dal Maso, M., Nilsson, E. D., Lehtinen, K. E. J., and Kulmala, M.: On particle formation prediction in continental boreal forest using micrometeorological parameters, J. Geophys. Res., 108, 4377, doi:10.1029/2002JD002850, 2003.

Dal Maso, M., Kulmala, M., Riipinen, I., Wagner, R., Hussein, T., Aalto, P. P., and Lehtinen, K. E. J.: Formation and growth of fresh atmospheric aerosols: eight years of aerosol size distribution data from SMEAR II, Hyytiälä, Finland, Boreal Environ. Res., 10, 323-336, 2005.

Dal Maso, M., Sogacheva, L., Aalto, P. P., Riipinen, I., Komppula, M., Tunved, P., Korhonen, L., Suur-Uski, V., Hirsikko, A., Kurtén, T., Kerminen, V.-M., Lihavainen, H., Viisanen, Y., Hansson, H.-C., and Kulmala, M.: Aerosol size distribution measurements at four Nordic field stations: identification, analysis and trajectory analysis of new particle formation bursts, Tellus B, 59, 350-361, 2007.

Draxler, R. R. and Hess, G. D.: An overview of the HYSPLIT_4 modelling system for trajectories, dispersion and deposition, Aust. Meteorol. Mag., 47, 295-308, 1998.

Draxler, R. R. and Hess, G. D.: Description of the HYSPLIT_4 modeling system, NOAA Technical Memorandum ERL ARL-224, http://www.arl.noaa.gov/documents/reports/arl-224. pdf, 2010.

Ehn, M., Thornton, J. A., Kleist, E., Sipilä, M., Junninen, H., Pullinen, I., Springer, M., Rubach, F., Tillmann, R., Lee, B., LopezHilfiker, F., Andres, S., Acir, I.-H., Rissanen, M., Jokinen, T., Schobesberger, S., Kangasluoma, J., Kontkanen, J., Nieminen, T., Kurtén, T., Nielsen, L. B., Jørgensen, S., Kjaergaard, H. G., Canagaratna, M., Dal Maso, M., Berndt, T., Petäjä, T., Wahner, A., Kerminen, V.-M., Kulmala, M., Worsnop, D. R., Wildt, J., and Mentel, T. F.: A large source of low-volatility secondary organic aerosol, Nature, 506, 476-479, 2014.

Häkkinen, S. A. K., Manninen, H. E., Yli-Juuti, T., Merikanto, J., Kajos, M. K., Nieminen, T., D’Andrea, S. D., Asmi, A., Pierce, J. R., Kulmala, M., and Riipinen, I.: Semi-empirical parameterization of size-dependent atmospheric nanoparticle growth in 
continental environments, Atmos. Chem. Phys., 13, 7665-7682, doi:10.5194/acp-13-7665-2013, 2013.

Hakola, H., Tarvainen, V., Laurila, T., Hiltunen, V., Hellen, H., and Keronen, P.: Seasonal variation of VOC concentrations above a boreal coniferous forest, Atmos. Environ., 37, 1623-1634, 2003.

Hamed, A., Korhonen, H., Sihto, S.-L., Joutsensaari, J., Järvinen, H., Petäjä, T., Arnold, F., Nieminen, T., Kulmala, M., Smith, J. N., Lehtinen, K. E. J., and Laaksonen, A.: The role of relative humidity in continental new particle formation, J. Geophys. Res., 116, D03202, doi:10.1029/2010JD014186, 2011.

Hari, P. and Kulmala, M.: Station for measuring ecosystematmosphere relations (SMEAR II), Boreal Environ. Res., 10, 315-322, 2005.

Hussein, T., Junninen, H., Tunved, P., Kristensson, A., Dal Maso, M., Riipinen, I., Aalto, P. P., Hansson, H.-C., Swietlicki, E., and Kulmala, M.: Time span and spatial scale of regional new particle formation events over Finland and Southern Sweden, Atmos. Chem. Phys., 9, 4699-4716, doi:10.5194/acp-9-4699-2009, 2009.

Hyvönen, S., Junninen, H., Laakso, L., Dal Maso, M., Grönholm, T., Bonn, B., Keronen, P., Aalto, P., Hiltunen, V., Pohja, T., Launiainen, S., Hari, P., Mannila, H., and Kulmala, M.: A look at aerosol formation using data mining techniques, Atmos. Chem. Phys., 5, 3345-3356, doi:10.5194/acp-5-3345-2005, 2005.

Kulmala, M. and Kerminen, V.-M.: On the formation and growth of atmospheric nanoparticles, Atmos. Res., 90, 132-150, 2008.

Kulmala, M., Toivonen, A., Mäkelä, J. M., and Laaksonen, A.: Analysis of the growth of nucleation mode particles observed in Boreal forest, Tellus B, 50, 449-462, 1998.

Kulmala, M., Vehkamäki, H., Petäjä, T., Dal Maso, M., Lauri, A., Kerminen, V.-M., Birmili, W., and McMurry, P. H.: Formation and growth rates of ultrafine atmospheric particles: a review of observations, J. Aerosol Sci., 35, 143-176, 2004.

Kulmala, M., Kontkanen, J., Junninen, H., Lehtipalo, K., Manninen, H. E., Nieminen, T., Petäjä, T., Sipilä, M., Schobesberger, S., Rantala, P., Franchin, A., Jokinen, T., Järvinen, E., Äijälä, M., Kangasluoma, J., Hakala, J., Aalto, P. P., Paasonen, P., Mikkilä, J., Vanhanen, J., Aalto, J., Hakola, H., Makkonen, U., Ruuskanen, T., Mauldin, R. L., Duplissy, J., Vehkamäki, H., Bäck, J., Kortelainen, A., Riipinen, I., Kurtén, T., Johnston, M. V., Smith, J. N., Ehn, M., Mentel, T. F., Lehtinen, K. E. J., Laaksonen, A., Kerminen, V.-M., and Worsnop, D. R.: Direct observations of atmospheric aerosol nucleation, Science, 339, 943-946, 2013.

Lappalainen, H. K., Sevanto, S., Bäck, J., Ruuskanen, T. M., Kolari, P., Taipale, R., Rinne, J., Kulmala, M., and Hari, P.: Daytime concentrations of biogenic volatile organic compounds in a boreal forest canopy and their relation to environmental and biological factors, Atmos. Chem. Phys., 9, 5447-5459, doi:10.5194/acp-9-5447-2009, 2009.

Lyubovtseva, Y. S., Sogacheva, L., Dal Maso, M., Bonn, B., Keronen, P., and Kulmala, M.: Seasonal variations of trace gases, meteorological parameters, and formation of aerosols in boreal forests. Boreal Environment Research 10, 493-510, 2005.
Nieminen, T., Asmi, A., Dal Maso, M., Aalto, P. P., Keronen, P., Petäjä, T., Kulmala, M., and Kerminen, V.-M.: Trends in atmospheric new particle formation: 16 years of observations in boreal forest environment, Boreal Environ. Res., 19 (Supplement B), 191-214, 2014.

Paasonen, P., Nieminen, T., Asmi, E., Manninen, H. E., Petäjä, T., Plass-Dülmer, C., Flentje, H., Birmili, W., Wiedensohler, A., Hõrrak, U., Metzger, A., Hamed, A., Laaksonen, A., Facchini, M. C., Kerminen, V.-M., and Kulmala, M.: On the roles of sulphuric acid and low-volatility organic vapours in the initial steps of atmospheric new particle formation, Atmos. Chem. Phys., 10, 11223-11242, doi:10.5194/acp-10-11223-2010, 2010.

Petäjä, T., Mauldin, III, R. L., Kosciuch, E., McGrath, J., Nieminen, T., Paasonen, P., Boy, M., Adamov, A., Kotiaho, T., and Kulmala, M.: Sulfuric acid and $\mathrm{OH}$ concentrations in a boreal forest site, Atmos. Chem. Phys., 9, 7435-7448, doi:10.5194/acp9-7435-2009, 2009.

Riipinen, I., Sihto, S.-L., Kulmala, M., Arnold, F., Dal Maso, M., Birmili, W., Saarnio, K., Teinilä, K., Kerminen, V.-M., Laaksonen, A., and Lehtinen, K. E. J.: Connections between atmospheric sulphuric acid and new particle formation during QUEST III-IV campaigns in Heidelberg and Hyytiälä, Atmos. Chem. Phys., 7, 1899-1914, doi:10.5194/acp-7-1899-2007, 2007.

Riuttanen, L., Hulkkonen, M., Dal Maso, M., Junninen, H., and Kulmala, M.: Trajectory analysis of atmospheric transport of fine particles, $\mathrm{SO}_{2}, \mathrm{NO}_{x}$ and $\mathrm{O}_{3}$ to the SMEAR II station in Finland in 1996-2008, Atmos. Chem. Phys., 13, 2153-2164, doi:10.5194/acp-13-2153-2013, 2013.

Sofiev, M., Siljamo, P., Valkama, I., Ilvonen, M., and Kukkonen, J.: A dispersion modelling system SILAM and its evaluation against ETEX data, Atmos. Environ., 40, 674-685, 2006.

Sogacheva, L., Saukkonen, L., Nilsson, E. D., Dal Maso, M., Schultz, D. M., De Leeuw, G., and Kulmala, M.: New aerosol particle formation in different synoptic situations at Hyytiälä, Southern Finland, Tellus B, 60, 485-494, 2008.

Stohl, A.: Computation, accuracy and applications of trajectories a review and bibliography, Atmos. Environ., 32, 947-966, 1998.

Stunder, B. J. B.: An assessment of the quality of forecast trajectories, J. Appl. Meteorol., 35, 1319-1331, 1996.

Weber, R. J., McMurry, P. H., Eisele, F. L., and Tanner, D. J.: Measurement of expected nucleation precursor species and 3 to $500 \mathrm{~nm}$ diameter particles at Mauna Loa Observatory, Hawaii, J. Atmos. Sci., 52, 2242-2257, 1995.

Yli-Juuti, T., Nieminen, T., Hirsikko, A., Aalto, P. P., Asmi, E., Hõrrak, U., Manninen, H. E., Patokoski, J., Dal Maso, M., Petäjä, T., Rinne, J., Kulmala, M., and Riipinen, I.: Growth rates of nucleation mode particles in Hyytiälä during 20032009: variation with particle size, season, data analysis method and ambient conditions, Atmos. Chem. Phys., 11, 12865-12886, doi:10.5194/acp-11-12865-2011, 2011. 